\title{
Alternative Religiosity and Non-institutionalized Spiritualities in Latin America
}

\author{
Frank Usarski ${ }^{1}$
}

Published online: 9 November 2018

(C) Springer Nature Switzerland AG 2018

With this issue, the JLAR continues its efforts to focus on topics that often play a subordinate role within the mainstream research of the religious field of Latin America. The reason for this relative neglection is not necessarily an expression of a missing academic interest in related aspects. Rather, it has to do with the sociological fuzziness and transitional nature of objects which makes it difficult to determine what exactly is to be studied and to which extent general conclusions could be drawn from the analyses.

These conditions also reverberate in the vague attempt to subsume the eight articles selected for the thematic session under the headline "Alternative Religiosity and Noninstitutionalized Spiritualities in Latin America." The phrase includes phenomena which the authors of the first four articles associate with the so-called New Age spirituality.

Anthony D'Andrea is fully aware of the blurriness of this expression and pleads for its conceptual clarification in comparison with forms of syncretic religiosity which do not fall under this category. For this purpose, the author refers to the already existing relevant scientific literature and elaborates on differences between North American/ European and Latin American variants of the New Age spirituality.

Marcelo Camurça dates the beginning of the New Age phenomenon to the 1980s and confirms its fundamental character as an eclectic spirituality of a variety of sources. He asks how this movement has developed in countries such as Mexico, Brazil, Argentina, and Uruguay under the influence of Latin American autochthonous religions over the last 20 years. At the same time, the author is interested in the impact of these specific developments on North American and European variants of the New Age.

Fatima Tavares and Carlos Caroso differentiate between global and culture-specific manifestations of the New Age. For the two authors, the New Age assumes the character of a "planetary movement" in cases in which therapeutic concepts and procedures propagated by representatives of the New Age have been incorporated into

Frank Usarski

usarski@pucsp.br

1 Pontifícia Universidade Católica de São Paulo, São Paulo, Brazil 
official modern medical systems. These "universal" dimension of the New Age should be categorically differentiated from forms of alternative religiosity that result from an integration of typical New Age beliefs and practices into particular regional contexts such as indigenous and African traditions in Brazil.

According to Silas Guerriero, the spiritual impact of the "New Age" movement on Brazilian's religious field is not limited to directly observable influences. As the author demonstrates in his article, there are indirect repercussions in the sense of a so-called New Age ethos. For the author, the term is suitable for the transversal presence of certain religious values that have been promoted by the Nova Era movement, but are also shared by Brazilians who would not declare themselves followers of the New Age.

A significant example of the interplay between autochthon religious traditions and transcultural New Age spirituality in Latin America is "Camino Rojo" (Red Path). In this issue, the movement, which originally emerged in Mexico, is approached from two perspectives.

Renee de la Torre offers an overview of the general characteristics of "Camino Rojo" particularly of the movement's inclination towards female spirituality, including the ideological foundation of this orientation, its spokeswomen and their global interconnectedness.

The article submitted by Juan Scuro, Guillermo Giucci, and Sebastián Torterola explores "Camino Rojo's" emergence and consolidation in Uruguay. The authors' focus lies on the biography and role of Alejandro Corchs, the charismatic key figure crucial to the establishment and evolution of the Uruguayan branch of the movement.

The overlapping of religion and healing in the context of alternative spirituality, already addressed by Tavares and Caroso, raises a number of questions which any researcher has to be answered according to the characteristics of his or her specific object under study. How are disease and healing defined within a religious group? What therapeutic competence is ascribed to certain spiritual authorities? In what sense and why these methods are attractive to a wider audience? What are the expectations of those who undergo these procedures? Does the experience of a successful healing lead to farer reaching religious consequences? Questions like these are instrumental for Emily Pierini's study of the religious foundation, therapeutic approaches and healing mediums of the Brazilian based Valley of the Dawn community.

Roberto Serafim Simões' article on "Early Latin American Esoteric Yoga as a New Spirituality in the First Half of the Twentieth Century" reminds us that the labeling of a religion as "new" or "alternative" depends on the socio-historical context. The author offers the biographical sketches of five protagonists of this "proto-yoga" and relates their particular contribution to contemporary institutionalized manifestations of Yoga in Latin America.

In addition to the eight articles selected for the thematic section, the reader of this JLAR-issue also finds two contributions rubricated as "original papers." The first was written by Robin Rodd and summarizes the results of a field research among the Piaroa that is an indigenous tribe mainly concentrated at the Venezuelan Orinoco Basin. The author's interest lies primarily on the worldview of this population, including the ethics narratively elaborated by charismatic shamans with reference to the common good of the tribe.

Magdalena Milsev'a article is based on an ethnographic study among the members of a Catholic charismatic church in Montevideo. The participation in the effervescent 
gatherings of the community made the author aware of a close connection between the experience of healing and conversion in the sense of the adoption of a new world view in which spiritual, somatic, and emotional aspects are integrated into a "holistic" spirituality symptomatic for Christian charismatic religiosity.

This issue is completed by two book reviews. Olga Lidia Olivas Hernández comments on a compilation of ethnographic studies conducted by Renne de la Torre and Cristina Gutiérrez Zúñiga, entitled Mismos pasos y nuevos caminos. La transnacionalización de la danza conchera Azteca (2017). Maurício G. Righi review is on the anthology Jews and Jewish Identities in Latin America: Historical, Cultural, and Literary Perspectives (2017) edited by Margalit Bejarano, Yaron Harel, Marta F. Topel, and Margalit Yosifon.

Publisher's note Springer Nature remains neutral with regard to jurisdictional claims in published maps and institutional affiliations. 